Journal homepage:http://www.interscience.org.uk

DOI:10.18535/ijahm/v8i1.01

Impact Factor: 4.415

\title{
Cranberry -A Natural Way of UTI Remedy
}

\author{
Dr. A.H. Ansari \\ Professor Chemistry Govt. P. G. College, Damoh [M.P] India
}

\begin{abstract}
UTI is very comman disease caused by E.coli, gram negative bacteria already present in intestine, Kidney and urinary tract. Alkaline condition favours the multiplication of bacteria. Presence of E.coli creats burning micturition, eargency of urine with trouble. Use of antibiotics and intake of excessive amount of water can cure it but leads some side effects. various research reveal that colourful berries especially 'Cranberry' is highly efficient to cure Eicole infection. As it contains numerous natural products as 'Antioxidants', which boost our immune system along with anticlinging property thus prevents bacterial adhesion on the wall of urinary tract as well as urinary bladder.
\end{abstract}

Keywords - Antioxidants, anticlinging, proanthocyanidine.

\section{Introduction :-}

Cranberries [1,2] are a group of evergreen shrubs belong to geuns 'Vaccinium'. Major species are V. oxycoccos and V. macrocarpum. Oxycoccos species is wide spread throughout temperate hemisphere, North Europe, North Asia and North America. V. microcarpum differs from oxycoccus in leaves being larger and apple like taste. It is a low creeping shrub 7-8 feet long with hairy stem. Flowers are dark pink. It is a major commercial crop in USA and Canada[3]. Indian cranberry is also known as 'Karonda' in Hindi. It is found in Nepal, Pakistan, Afghanistan and some parts of Africa. Its scientific name is 'carissa corandas or congesta'. It is also reffered as super food consisting of phyto nutrients like flavonoids and polyphenols which boost our immunity to fight against breast, prostate, colon cancer and protect from UTI.

Materia and Method:- Deep literature survey was carried out to evaluate the presence of 'Bioactive' constituents and health benefits of cranberries listed below.[4,5,6,7]

Table

\begin{tabular}{|l|l|l|}
\hline S.No & Bioactive Constituents & Health Benefits \\
\hline 1 & Polyphenols- catechin & $\begin{array}{l}\text { Inhibits proliferation of cancerous cells like } \\
\text { prostate,colon. Also useful in Alzheimer. }\end{array}$ \\
\hline 2 & $\begin{array}{l}\text { Pro-Anthocyanidin- A type of } \\
\text { flavonoid alongwith quercetin }\end{array}$ & $\begin{array}{l}\text { It exhibits anticlinging property,prevents } \\
\text { adhesion of E.coli and H. pylori, protecting } \\
\text { from UTI and stomach ulcer. }\end{array}$ \\
\hline 3 & Ursolic acid and Benzoic Acid & $\begin{array}{l}\text { Show Anti inflammatory and Analgesic } \\
\text { property thus relieves in burning } \\
\text { micturition. }\end{array}$ \\
\hline 5 & Anthocyanins & $\begin{array}{l}\text { Lower LDL and increase HDL }(320 \mathrm{mg} / \mathrm{d}) \\
\text { thus lowering cardiovascular risk. } \\
\text { Boost immunity. }\end{array}$ \\
\hline
\end{tabular}

Besides above one glass of juice of cranberry contains 46 calories along with Vitamin B1,B2,B3,Choline,Sodium,Potassium,Calcium and Phosphorous.

Result and Discussion :- Cranberry is also referred as 'Super food' loaded with enormous phytonutrients and Antioxidants $[8,9,10]$. According to 'British journal of nutrition intake of one glass cranberry juice daily increases HDL 10\% and lowers LDL cholesterol. American journal of Obstetrics and Gynecology says, 
Cranberry juice prevents E.coli and H. pylori adhesion on urinary tract, bladder and inner lining of stomach. It is also useful in Alzheimer, prostate and colon cancer due to rich antioxidant property.

Conclusion:-Majority of the society heavily depends on modern system of medicine. Use of new generation antibiotics and chemotherapeutics' are reducing our immune system in dreadful manner. Nature has been lost somewhere in our life. Cranberry and other berries can be beneficial to cure bacterial infection and proliferation of tumor cells in natural way, securing us from UTI, stomach ulcer, prostate and colon cancer specially country like India where water scarcity is a huge problem in the summer. As water scarcity in the body is directly responsible for UTI and stone formation.

\section{Refrences :-}

1. Stace, Cline, New flora of British Island (2010), 3Ed, Cambridge, UK, Cambridge Univ. press, p 512, ISBN-978-0521-70772-5.

2. 'Vaccinium' macrocarpon, 'Natural Resources Conservation Service', plants database, USDA .Retrieved 11 No 2014.

3. 'About Cranberries', Cranberry Institute, Archived from the original 9 Jan 2010, Retrieved 13 Nov 2009.

4. Cote, J caillet, S.Doyon G,Sylvain, J F,Lacroix, , Bioactive compounds in cranberry and their biological properties. Crit Rev. Food Sci. Nutr 2010, 50, 666-79.

5. Mckay, D L, Blemberg J B, Cranberries and cardiovascular disease risk factors. Nutr.Rev. 2007,65 490-502.

6. Cote J, caillet S, Doyon G, Sylvain, JF, Lacroix M,' Analysing cranberry bioactive compounds, Crit. Rev. Food Sci. Nutr, 2010, 50, 872-88.

7. Ikeda,Y, Murakami A, Ohigashi H. Ursolic acid, An anti and pro inflammatory tri terpenoid mol. Nutr. Food Res. 2008, 52, 26-42.

8. Avorn,J, Monane, M, Gurwitz J H, Glynn R J, Choodorskiy I, Lipstoz L A, Reduction of bacteria urea and pyuria after ingestion of cranberry Juice JAMA, 1994, 271,751-4.

9. Slothers L A, Randomised trial to evaluate effectiveness and cost effectiveness of naturopathic cranberry products as prophylaxis against UTI in women. Canc. journal of urology 2002, 9, 1558-62.

10. Kalgaonkar S, Gross HB, Yokoyoma W, Keen CL. Effects of flavonol rich diet select cardiovascular parameters in a golden Syrian hamster model J. med. food 2010,13,108-15. 